\title{
Idiopathic Intracranial Hypertension - Pathophysiology Based on Case Series
}

\author{
Srdjan Ljubisavljević1,2, Jasna Zidverc Trajković3, ${ }^{3,4}$ \\ ${ }^{1}$ University of Niš, Faculty of Medicine, Niš, Serbia \\ ${ }^{2}$ Clinic of Neurology, Clinical Center Niš, Serbia \\ ${ }^{3}$ University of Belgrade, Faculty of Medicine, Belgrade, Serbia \\ ${ }^{4}$ Clinic of Neurology, Clinical Center of Serbia, Belgrade, Serbia
}

\section{SUMMARY}

According to the definition, idiopathic intracranial hypertension (IIH) is a pathological state characterized by an increase in intracranial pressure; however, there are no obvious intracranial pathological processes. The pathophysiology of this disorder is not clear, although there are many reports related to it.

We present an overview of possible etiopathogenetic mechanisms, clinical presentations and therapeutic interventions from a series of patients hospitalized with the clinical picture and final diagnosis of idiopathic intracranial hypertension (IIH). All data were collected from the moment of IIH diagnosis as well as three months later.

The obtained data showed that IIH is a disease that primarily affects obese women in early and midlife. The positive correlation between values of cerebrospinal fluid pressure and body mass index was observed. The disorders of sexual hormones were identified as a possible etiology for IIH female patients. Headache, papilloedema, decreased visual acuity, vertigo and cranial nerve palsy were identified as the most prevalent IIH clinical presentations. The existence of stenosis and hypoplasia of the sigmoid and transverse sinus were confirmed only in one third of IIH patients. Pharmacotherapy combined with weight loss was efficacious in a large number of patients. In this series, there were no short-term consequences of IIH.

The results suggest the importance of early and accurate looking for IIH in obese early and midlife women with any hormonal imbalances having a variety of neurological expression, mostly presented as headaches and visual disturbances. Early detection of IIH might influence the timely treatment and prevent far-reaching and severe clinical consequences.

Key words: idiopathic intracranial hypertension, headache, pathophysiology

Corresponding author:

Srdjan Ljubisavljević

Email: srljub@gmail.com 


\section{INTRODUCTION}

According to the definition, idiopathic intracranial hypertension (IIH) is a pathological state characterized by an increase in intracranial pressure; however, there are no obvious intracranial pathological processes. The pathophysiology of this disorder is not clear, although there are many reports related to it $(1,2)$.

It is widely accepted that IIH usually affects patients who are between 20 and 40 years of age and is combined with obesity. Nevertheless, there are cases when IIH occurs even earlier, although it is not then generally accompanied by obesity (3). Women are more affected than men, 4 to even 15 times, as has been estimated (4). The frequency of $\mathrm{IIH}$ occurrence is $1-2$ per 100.000 of the general population, and it is highest in the population of obese women (5). The estimations show that the total IIH widespread presence corresponds to the rate of obesity in an area (1). Regarding the existence of IIH, clinical phenotypes with poor clinical presentation, when there are no diagnostic considerations of the disorder, the real incidence and prevalence rates are estimated to be higher than mentioned (6).

The possible etiological parameters of this disorder suggest that the basis for $\mathrm{IIH}$ occurrence might be: heredity; CSF production disorder in the sense of increased production or decreased reabsorption; cerebral edema; increased pressure in the intracranial venous system $(6,7)$; obesity $(6)$; homeostatic disorder of certain cytokines, such as IL-1 $\alpha$, and leptin (8); and female sexual hormone disorders promoting coagulation $(9,10)$.

$\mathrm{IIH}$ can be presented as a wide spectrum of neurological disorders, although the usual clinical presentation of IIH includes headache, vertigo and nausea, sometimes accompanied by vomiting (11). The occurrence of focal neurological signs, except for the impairment of the VI nerve, is very rare, and requires additional diagnostic work-up for the underlying pathological processes (11). Visual symptoms and signs, in the form of transient visual acuity impairment, dimmed and blurred vision, photophobia, and diplopia occur in 40-70\% of patients with $\mathrm{IIH}$ (12). Even though optic nerve papilloedema is considered to be a cardinal sign of $\mathrm{IIH}$, cases of IIH without papilloedema have been reported (13).
In order to diagnose $\mathrm{IIH}$, all diagnostic criteria have to be fulfilled, called the Dandy criteria introduced in 1937, later improved and now referred to as the "modified Dandy criteria". These criteria include: 1) signs and symptoms of increased intracranial pressure; 2) no other neurological abnormalities or impaired level of consciousness; 3) elevated CSF opening pressure with normal CSF composition; (4) a neuroimaging study that shows no etiology for increased ICP; (5) no other cause for intracranial hypertension found (Table 1) (14). Differential diagnosis, because of similar clinical presentations, includes: thrombosis of dural venous sinuses, hydrocephalus, cerebral mass effect lesions, hypertensive encephalopathy, optic disc anomalies, and secondary intracranial hypertension (15). Some systemic diseases, such as systemic lupus erythematosus, Behcet's disease, uremia, iron-deficiency anemia, Addison's disease, hypothyroidism, polycystic ovary syndrome, as well as the use of some drugs (tetracyclines, nalidixic acid, fluoroquinolones, oral contraception, danazol, progesterone, lithium, vitamin A, sulfamethoxazole, growth hormone etc.), can accompany the occurrence of IIH (1). IIH can also be accompanied by autoimmune diseases and sleep apnea (16). Even early descriptions of $\mathrm{IIH}$ suggested differences in the presence and duration of clinical symptoms in IIH patients. Described symptoms and signs can be short-term and transient, but even the less frequent ones are very persistent and durable, with relapses and therapeutic resistance $(15,17)$.

We present an overview of possible etiopathogenetic mechanisms, clinical presentations, and therapeutic interventions during the 15-year experience with a series of patients hospitalized with the clinical picture and final diagnosis of $\mathrm{IIH}$.

\section{MATERIAL AND METHODS}

This study implied a retrospective and cross-sectional analysis of patients suffering from $\mathrm{IIH}$ who were diagnosed at the Clinic for Neurology, Clinical Center of Serbia and Headache Ambulance of Clinic for Neurology, Clinical Center Niš, from January 2000 to December 2015. The study was approved by the Local Ethics Committee and was performed in strict accordance with Health Insurance Portability and 
Table 1. Diagnostic Criteria of Idiopathic Intracranial Hypertension (Friedman and Jacobson, 2002)

\begin{tabular}{|c|c|}
\hline & intracranial hypertension or papilloedema \\
\hline - & Intracranial pressure, as measured in the lateral decubitus position, is elevated \\
\hline - & The composition of the cerebrospinal fluid is normal \\
\hline " & There is no evidence of hydrocephalus, mass, structural or vascular lesion \\
\hline - & No other cause of intracranial hypertension has been identified \\
\hline
\end{tabular}

Accountability Act regulations (Declaration of Helsinki). Informed consent was obtained from all the study subjects.

The diagnostic work-up for patients who were thought to have IIH included ophthalmologic, neurologic and neuroimaging examinations along with the analysis of cerebrospinal fluid (CSF).

To confirm the presence or absence of papilloedema or secondary optic atrophy, all IIH patients were examined by neuro-ophthamologist, who used indirect ophthalmoscopy with the intention of excluding the minor disc swelling or subtle papilloedema. The neuro-ophthamologist reviewed kinetic and/or static perimetry for each case and judged the visual fields. The presence and type of headache and the occurrence of vertigo, nausea, and other symptoms were tested in every individual case. The usual laboratory analyses of serum and CSF, brain CT, brain MRI, and MRI venography were conducted.

Lumbar punctures (LPs) were performed in all patients, in the lateral decubitus position, on a surface level. A standard spinal needle was used. The opening pressure was recorded with a manometer positioned at a $90^{\circ}$ angle to the spinal canal with the patient's knees and hip in the extended position and neck straightened. CSF pressure was recorded when the patient was relaxed and the pressure values stabilized. All patients met the standard criteria for $\mathrm{IIH}$, Table 1 (14).

The retrospective analysis of 4.126 patients' records contained the socio-demographic data, description of neurological functional condition and associated symptoms, other disorders, data from personal to family history, results of additional examinations, as well as treatment modalities and their efficacy. We included only 18 patients diagnosed with definite
$\mathrm{IIH}$, according to the current diagnostic criteria (14). All data were collected from the moment of $\mathrm{IIH}$ diagnosis as well as three months later.

We excluded patients with secondary intracranial hypertension, e.g. intracranial mass lesions, traumatic brain injury, stroke, dural arteriovenous fistula, hydrocephalus and especially venous sinus thrombosis.

\section{RESULTS}

We examined the data obtained from 18 patients with IIH, 15 females and 3 males, ranging from 18 to 52 years of age. The majority of the IIH patients (13 women) were obese, with BMI values ranging from $31 \mathrm{~kg} / \mathrm{m} 2$ to 39.1 $\mathrm{kg} / \mathrm{m} 2$, while in other patients ( 3 men and 2 women), BMI values ranged between $24.5 \mathrm{~kg} / \mathrm{m} 2$ and $29.1 \mathrm{~kg} / \mathrm{m} 2$. Seven patients were current smokers, while 5 female patients had been treated with hormonal therapy in duration of two years. These data are presented in Table 2 .

The presentation of IIH was not asymptomatic in any of the patients in the examined series. In 13 patients, the existence of optic nerve papilloedema was registered, in 5 of them with unilateral localization and in 8 with bilateral localization; 14 patients had vision problems of decreased visual acuity (10 patients) and/or narrowing of the visual field (4 patients). Sixteen patients had headaches (the results of the headache features of the majority of IIH patients presented here were published in our previous paper (18), 3 patients had tinnitus, 5 patients had vertigo, and 5 had an impairment of the III and VI cranial nerves (diplopia was reported by 2 patients). Internal jugular venous stenosis in the upper parts was established in one patient and confirmed by MRI venography. Stenosis of the 
Table 2. Demographic and clinical data of IIH patients

\begin{tabular}{|c|c|c|c|c|c|}
\hline Patient & $\begin{array}{c}\text { Female/ } \\
\text { Male }\end{array}$ & $\begin{array}{c}\text { Age } \\
\text { (years) }\end{array}$ & $\begin{array}{c}\text { Smoking/ } \\
\text { Alcohol/ } \\
\text { Drugs }\end{array}$ & $\begin{array}{c}\text { Obesity } \\
(\text { BMI>30 } \\
\left.\text { kg/m }{ }^{2}\right) \\
\end{array}$ & Co morbidities \\
\hline 1 & $\mathrm{M}$ & 33 & - & - & - \\
\hline 2 & $\mathrm{~F}$ & 37 & - & + & Infertility (under hormones) \\
\hline 3 & $\mathrm{~F}$ & 20 & Smoking & + & - \\
\hline 4 & $\mathrm{~F}$ & 21 & Smoking & + & - \\
\hline 5 & $\mathrm{~F}$ & 40 & Smoking & + & - \\
\hline 6 & $\mathrm{~F}$ & 31 & - & + & Polycystic ovary syndrome (under hormones) \\
\hline 7 & $\mathrm{~F}$ & 23 & Smoking & + & - \\
\hline 8 & $\mathrm{~F}$ & 23 & - & + & - \\
\hline 9 & $\mathrm{~F}$ & 42 & - & - & - \\
\hline 10 & $\mathrm{~F}$ & 51 & - & + & - \\
\hline 11 & $\mathrm{~F}$ & 19 & - & + & Prolactinoma in remission \\
\hline 12 & $\mathrm{M}$ & 50 & - & - & - \\
\hline 13 & $\mathrm{~F}$ & 37 & Smoking & + & - \\
\hline 14 & $\mathrm{~F}$ & 52 & & + & - \\
\hline 15 & $\mathrm{~F}$ & 29 & & + & Polycystic ovary syndrome (under hormones) \\
\hline 16 & $\mathrm{~F}$ & 40 & & + & Infertility (under hormones) \\
\hline 17 & $\mathrm{~F}$ & 18 & Smoking & - & - \\
\hline 18 & $\mathrm{M}$ & 41 & Smoking & - & - \\
\hline
\end{tabular}

sigmoid and transversal sinus was verified in 4 patients. The presenting symptoms and signs are shown in Table 3.

The values of parameters of inflammation, immune and hemocoagulation status were in the physiological range in all patients, in both sera and CSF. The obtained values of CSF pressure were in the range of 250 to $680 \mathrm{~mm} \mathrm{H} 2 \mathrm{O}$ (median $320 \mathrm{~mm} \mathrm{H} 2 \mathrm{O}$ ). The ratio of the obtained values of CSF pressure and
BMI are shown in Figure 1. The positive correlation between BMI and values of CSF pressure was confirmed $(\mathrm{p}<0.01, \mathrm{r}=0.94)$. There were no direct or delayed complications of LP.

All IIH patients were treated with pharmacological therapy. Acetazolamide was started in 14 patients, at a daily dose of 250 to $500 \mathrm{mg}$ with a gradual increase up to the final daily dose of $1000 \mathrm{mg}$ per day, while topiramate

Table 3. Clinical and radiological findings of IIH patients

\begin{tabular}{c|c}
\hline \hline Clinical symptoms and signs & Number of patients \\
\hline Papilloedema & Unilateral - 5 (27.7 \%); Bilateral - 8 (44.4 \%) \\
\hline Visual loss vision acuity decreased vision field depth & $10(55.5 \%) 4(22.2 \%)$ \\
\hline Diplopia & $2(11.1 \%)$ \\
\hline Headache & $16(88.8 \%)$ \\
\hline Tinnitus & $3(16.6 \%)$ \\
\hline Vertigo/dizziness & $5(27.7 \%)$ \\
\hline Cranial nerve palsy & $5(27.7 \%)$ \\
\hline No clinical symptoms and signs & $0(0 \%)$ \\
\hline Radiological findings & $5(27.7 \%)$ \\
\hline \hline Stenosis and/or hypoplasia of the sigmoid or transverse \\
sinus
\end{tabular}


Table 4. The drugs` effects on IIH clinical presentation on first control (3 months later)

\begin{tabular}{l|c|c|c|c}
\hline \hline $\begin{array}{l}\text { Pharmacological and } \\
\text { other interventions }\end{array}$ & $\begin{array}{c}\text { Number of } \\
\text { patients }\end{array}$ & $\begin{array}{c}\text { Remission/ } \\
\text { Stable phase }\end{array}$ & Improving & Deteriorating \\
\hline Acetazolamide & $14(83.3 .7 \%)$ & $5(35.7 \%)$ & $9(64.3 \%)$ & $/$ \\
\hline Topiramate & $4(22.2 \%)$ & $/$ & $4(100 \%)$ & $/$ \\
\hline Weight loss * & $9(50 \%)$ & $/$ & $9(100 \%)$ & $/$ \\
\hline $\begin{array}{l}\text { Other drugs and/or surgical } \\
\text { interventions }\end{array}$ & $/$ & $/$ & $/$ & $/$ \\
\hline \hline
\end{tabular}

Patients used acetazolamide in dose of $1000 \mathrm{mg}$ per day, topiramate in dose of $200 \mathrm{mg}$ per day,

* 4 patients used topiramate, 5 patients used acetazolamide. Weight loss were ranged between $5 \%$ to $15 \%$ of the initial weight

was started in 4 patients, at a daily dose of 25 to $50 \mathrm{mg}$ with a gradual increase dose to $200 \mathrm{mg}$ per day. The majority of IIH patients achieved improvement in clinical presentation (complete reduction of the initial clinical difficulties) by the time of the first control examination, which was after 3 months. In 5 of IIH patients the clinical presentation reflected in incomplete reduction so they were considered as being in the stable phase of IIH. Weight loss was revealed as a parameter for $\mathrm{IIH}$ improvement in a half of IIH patients. In our series, there were no IIH patients considered for the surgical treatments. Data are presented in Table 4.

\section{DISCUSSION}

The results obtained here clearly confirm that IIH is a disease that primarily affects obese women at their early and midlife, as it has been suggested earlier (19). Although the results indicate that secondary etiology should be considered in IIH male patients who are not obese, especially autoimmune etiology (20), the diagnostic procedure for these patients in our series did not reveal secondary conditions. The very fact that the disease is more common in women than in men immediately indicates a role of female sexual hormones in IIH onset and course. There are results suggesting that hormonal imbalance could be a possible basis of IIH (21). In our IIH female patients, a hormonal disorder was identified even before the development of $\mathrm{IIH}$ clinical presentation. They were undergoing a chronic hormone-replacement therapy within two years as the treatment for primary infertility or polycystic ovary syndrome or were undergoing a supportive hormonal therapy for the treatment of prolactinoma. There are also studies that support the occurrence of IIH in the mentioned states (22, 23). The IIH in these conditions might appear due to the stimulatory effect of estrogen on CSF production $(24,25)$, which might be especially potentiated in obese patients (25).

The relation between obesity and IIH onset is far stronger, considering the increase of the relative risk for $\mathrm{IIH}$ onset in obese patients with increased BMI (26). Here, the obtained correlation between BMI and CSF pressure values is in agreement with previously mentioned facts (Figure 1). Some results support the same correlation in relation to an increase in patient's age (27). The obesity does not affect only the onset but also the IIH course and its outcome, degree of 


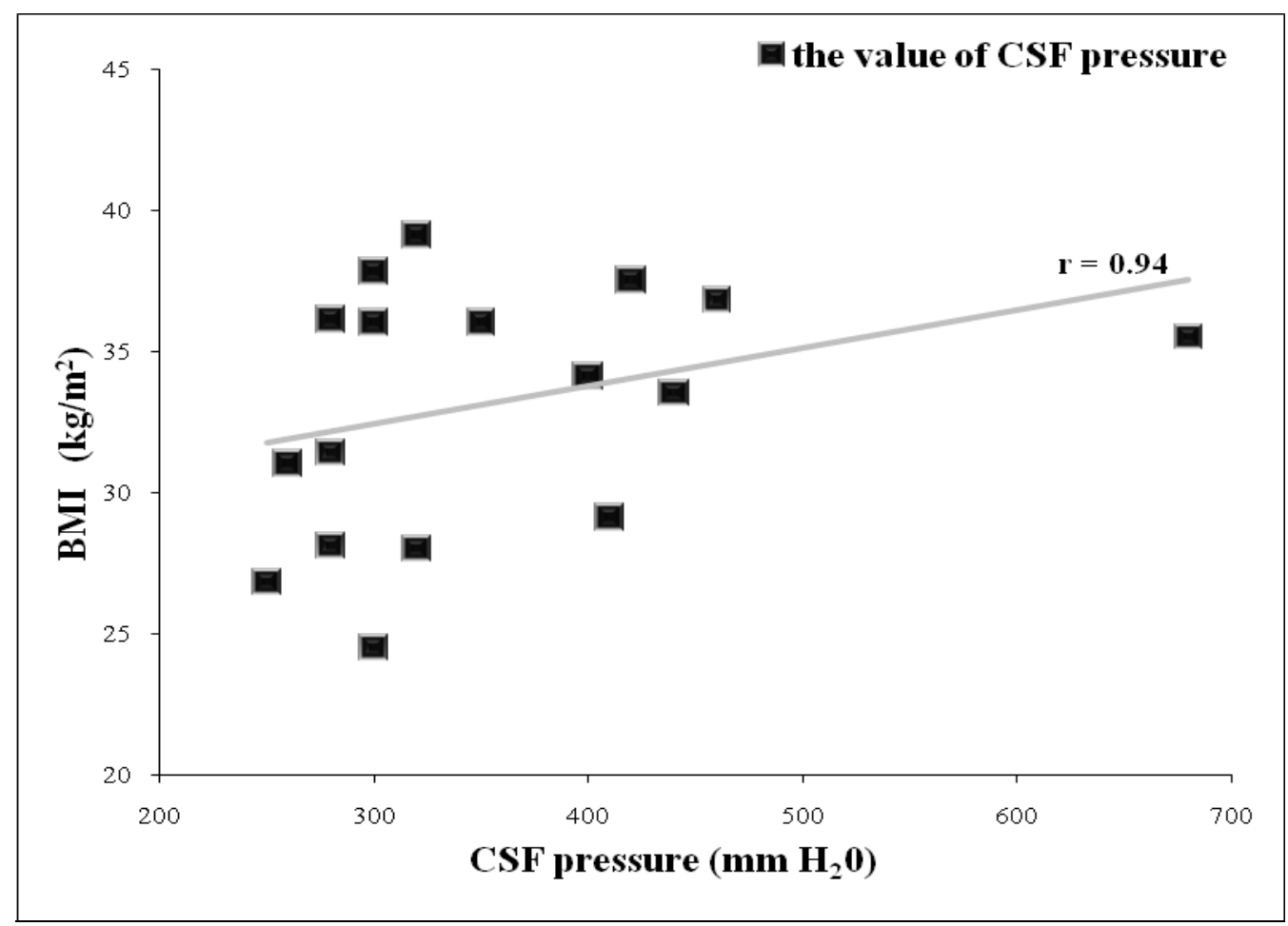

Figure 1.The values of CSF pressure regarding patients' BMI

Figure legend - Increased CSF pressures (200-mm $\mathrm{H}_{2} \mathrm{O}$ in the non-obese, 250- $\mathrm{mm} \mathrm{H}_{2} \mathrm{O}$ in the obese) measured by lumbar puncture in the lateral decubitus position. Normal CSF chemistry and cellularity were observed in all study patients. BMI was calculated as ratio of body weight $(\mathrm{kg})$ and square values of body height $(\mathrm{m})$. Normal weight $=18.5-24.9$, Overweight $=25-29.9$, Obesity $=$ BMI of 30 or greater. Linear correlation analysis was performed.

recovery, primarily from vision impairment (28). In the present study, the obtained results support these facts, whereas in patients with weight loss a better clinical recovery was achieved (Table 4). On the other hand, in our study, approximately a quarter of patients were not obese, which is again similar to the results from the similar IIH series reported by others (27), as our results also correspond to the results from a study testing the relationship between obesity and $\mathrm{IIH}$ in a femaleonly population $(29,30)$.

Obesity plays a possible role, but it is purely hemodynamic, because the pressure in the venous system is increased due to the increased intraabdominal and intrathoracic pressure. Because of this, the physiological course and CSF reabsorption are decreased, and intracranial pressure is increased $(31,32)$. Recent studies which dealt with obesity as a proinflammatory state including the excessive production of leptin and IL-6, IL-8, and IL- $1 \mathrm{~b}$ have shown that alterations in their concentrations play a significant role for the development of $\mathrm{IIH}$ and other pathological states related to obesity (8). In our study, the obtained values for the general inflammatory parameters do not support the theory of the existence of a proinflammatory state (data not shown). However, subtle changes that could be the basis of that proinflammation cannot be proved by the routine methods used in our research. In that context, it is interesting to note that smoking was revealed in less than $40 \%$ of our IIH patients. Smoking is considered to be a direct trigger of oxidative and inflammatory processes (8). It might affect the coexistence of IIH and proinflamatory condition in our IIH patients. There are studies indicating also a strong relationship between smoking and IIH (33).

The existence of cranial vessels abnormality (venous stenosis and hypoplasia of the sigmoid and transverse sinus) was confirmed in less than $30 \%$ of IIH patients. In many reports, changes on endocranium venous system and $\mathrm{IIH}$ onset are 
related to each other $(31,34-36)$. Some studies suggest that this relationship is accidental and/or indicate the reversibility of venous stenosis, which withdraws by the normalization of CSF pressure (37). This suggests that IIH might be both a cause and a consequence of the mentioned disorders. Finally, up to $30 \%$ of the healthy population can have changes in the endocranial venous system without any clinical presentations (38).

Although IIH is considered to be a disease whose causes are only assumed, IIH symptoms and signs are anyway defined. In the patients in our study, IIH was clinically manifested by headaches ( $\sim 90 \%)$, visual loss $(\sim 80 \%)$ and papilloedema $(\sim 75 \%)$, which is in agreement with similar previous published results (35). Headache is caused by the compression of pain-sensitive structures (nerves and vasculature), which causes neuroinflammation and initiates the secretion of the mediator of aseptic inflammation (34). The visual impairments are caused by the obstruction of axonal transport at the level of the optic disc (34, 39). Although it was long believed that optic nerve papilloedema was the chief clinical sign of $\mathrm{IIH}$, more and more reports show that this change does not occur in the eye fundus $(12,13)$. It was the case $\sim 30 \%$ of our patients (Table 3 ). Some authors have recruited this IIH phenotype from patients who suffer from chronic forms of primary headache (migraine or tension type headache), even in $10 \%$ $15 \%$ patients $(13,18)$.

In our case series, there was no clinically silent $\mathrm{IIH}$, although we observed vertigo and cranial nerve palsy in a far lower percentage $(\sim 30 \%)$. It has been hypothesized that vertigo, tinnitus and nausea associated with IIH are due to compression of the vestibulocochlear nerve from the increased CSF pressure. The vestibulocochlear nerve is in relation to the meninges, in a fashion similar to that of the optic nerve, making it vulnerable to compression that can cause nerve dysfunction $(24,40)$.

Acetazolamide is recognized as the standard therapy for IIH treatment (15). As a carbonic anhydrase inhibitor, acetazolamide is used to block the transepithelial transport of $\mathrm{Na}+$ ion, and in this way reduce CSF production and improve the clinical presentation IIH $(41,42)$. Although there are some doubts about the efficacy of this drug (11, $13)$, the majority of our patients $(\sim 80 \%)$ experienced remission and clinical improvement. It seems that acetazolamide achieves the greatest effect in combination with weight loss, which was the case in our study patients. Reduction of body weight is considered to be an independent predictor of good outcome especially regarding impaired vision and the prevention of its irreversible complication (11). In one follow-up study, it has been confirmed that recurrences of IIH were inversely correlated with weight loss (26). Also, topiramate was the absolutely effective drug in our cases of IIH. This beneficial effect might be the coexistence of independent effect on ion channels with topiramate related side effect weight loss $(43,44)$. The persistent course of IIH was also reported (42).

The visual impairment due to $\mathrm{IIH}$ is the most serious complication $(1,5)$. Considering that the time for these complications can be relatively long, even longer than five years, a long-term follow-up of patients is necessary, even in the cases of good primary response to therapy and the absence of other clinical manifestations of IIH (41, $45)$. In the case series presented here, there were no short-term consequences of IIH. It must be taken as a result of a short time from the moment of setting the diagnosis of IIH and the first control, three months later.

The main limitations of the present study are its retrospective nature and the absence of the follow-up of patients, as well as a small number of patients. However, the agreement with findings of previous IIH studies suggests the validity of the results presented here. In that sense, the authors consider their report as a small contribution to the diverse and incomplete knowledge of the pathophysiology, clinical presentation and therapy of $\mathrm{IIH}$, which represents rare but possibly a great diagnostic and therapeutic challenge.

\section{CONCLUSION}

The suspicion on IIH must be made in all obese, early and midlife women with any proinflammatory condition and hormonal imbalances, having a variety of neurological expressions, mostly presented as headaches and visual disturbances. Early detection of IIH might influence the timely treatment and prevent farreaching and severe clinical consequences 


\section{ACKNOWLEDGMENTS}

This work was started during the study residence of Dr. Srdjan Ljubisavljević at the Clinic for Neurology, Clinical Center of Serbia. The author is indebted to the Clinic staff, prof. $\mathrm{dr}$ Vladimir Kostić, prof. dr Nadežda Čovičković Šternić and the other residents for their understanding and support during his engagement.

\section{References}

1. Dhungana S, Sharrack B, Woodroofe N. Idiopathic intracranial hypertension. Acta Neurol Scand 2010; 121 (2): 71-82.

http://dx.doi.org/10.1111/j.1600-0404.2009.01172.x

2. Yri HM, Wegener $M$, Sander $B$, Jensen $R$. Idiopathic intracranial hypertension is not benign: a long-term outcome study. J Neurol 2012; 259 (5): 886-94.

http://dx.doi.org/10.1007/s00415-011-6273-9

3. Bruce BB, Kedar S, Van Stavern GP, et al. Idiopathic intracranial hypertension in men. Neurology 2009; 72 (4): 304-9.

http://dx.doi.org/10.1212/01.wnl.0000333254.84120.f5

4. Schmidt C, Wiener E, Hoffmann J, et al. Structural Olfactory Nerve Changes in Patients Suffering from Idiopathic Intracranial Hypertension. PLoS ONE 2012; 7(4): e35221.

http://dx.doi.org/10.1371/journal.pone.0035221

5. Raoof N, Sharrack B, Pepper IM, Hickman SJ. The incidence and prevalence of idiopathic intracranial hypertension in Sheffield, UK. Eur J Neurol 2011; 18 (10): 1266-8.

http://dx.doi.org/10.1111/j.1468-1331.2011.03372.x

6. Friesner D, Rosenman R, Lobb BM, Tanne E. Idiopathic intracranial hypertension in the USA: the role of obesity in establishing prevalence and healthcare costs. Obes Rev 2011; 12 (5): 372-80. http://dx.doi.org/10.1111/j.1467-789X.2010.00799.x
7. Kerty E, Heuser K, Indahl UG, et al. Is the brain water channel aquaporin- 4 a pathogenetic factor in idiopathic intracranial hypertension? Results from a combined clinical and genetic study in a Norwegian cohort. Acta Ophthalmol 2013; 91 (1): 88-91. http://dx.doi.org/10.1111/j.1755-3768.2011.02231.x

8. Dhungana S, Sharrack B. Cytokines and Chemokines in Idiopathic Intracranial Hypertension. Headache 2009; 49 (2): 282-5. http://dx.doi.org/10.1111/j.1526-4610.2008.001329.x

9. Bono F, Giliberto C, Mastrandrea C, et al. Transverse sinus stenoses persist after normalization of the CSF pressure in $\mathrm{IIH}$. Neurology 2005; 65: 1090-3.

http://dx.doi.org/10.1212/01.wnl.0000178889.63571.e5

10. Wall M. Idiopathic Intracranial Hypertension. Neurol Clin 2010; 28(3): 593-617. http://dx.doi.org/10.1016/j.ncl.2010.03.003

11. Ball AK, Howman A, Wheatley $\mathrm{K}$, et al. A randomised controlled trial of treatment for idiopathic intracranial hypertension. J Neurol 2011; 258 (5): 874-81.

http://dx.doi.org/10.1007/s00415-010-5861-4

12. Thurtell M, Newman N, Biousse V. Visual Loss Without Papilledema in Idiopathic Intracranial Hypertension. J Neuro-Ophthalmol 2010; 30 (1): 968.

http://dx.doi.org/10.1097/WNO.0b013e3181c5d0bc 
13. Digre KE, Nakamoto BK, Warner JEA, et al. A Comparison of Idiopathic Intracranial Hypertension With and Without Papilledema. Headache 2009; 49: 187. http://dx.doi.org/10.1111/j.1526-4610.2008.01324.x

14. Friedman DI, Jacobson DM. Diagnostic criteria for idiopathic intracranial hypertension. Neurology 2002; 59 (10): 1492-5.

http://dx.doi.org/10.1212/01.WNL.0000029570.69134.1B

15. Skau M, Brennum J, Gjerris F, Jensen R. What is knew about idiopathic intracranial hypertension? An updated review of mechanism and treatment. Cephalalgia 2005; 26: 384-99. http://dx.doi.org/10.1111/j.1468-2982.2005.01055.x

16. Purvin VA, Kawasaki A, Yee RD. Papilledema and obstructive sleep apnea syndrome. Arch Ophthalmol 2000; 118 (12): 1626-30.

http://dx.doi.org/10.1001/archopht.118.12.1626

17. Mensah A, Milea D, Jensen R, Fledelius H. Persistent visual loss in malignant idiopathic intracranial hypertension. Acta Ophthalmol 2009; 87 (8): 934-6.

http://dx.doi.org/10.1111/j.1755-3768.2009.01706.x

18. Ljubisavljevic S, ZidvercTrajkovic J CovickovicSternic $\mathrm{N}$, et al. Idiopathic intracranial hypertension from the perspective of headache centre. Acta Neurol Belg 2013, 113(4): 487-92. http://dx.doi.org/10.1007/s13760-013-0228-0

19. Lecube A, Poca MA, Colomé N, et al. Proteomic Analysis of Cerebrospinal Fluid from Obese Women with Idiopathic Intracranial Hypertension: A New Approach for Identifying New Candidates in the Pathogenesis of Obesity. J Neuroendocrinol 2012; 24 (6): 944-52. http://dx.doi.org/10.1111/j.1365-2826.2012.02288.x

20. Tse C, Klein R. Intracranial hypertension associated with systemic lupus erythematosus in a young male patient. Lupus 2013; 22 (2): 205-12. http://dx.doi.org/10.1177/0961203312464804

21. Peng KP, Fuh JL, Wang SJ. High-pressure headaches: idiopathic intracranial hypertension and its mimics. Nat Rev Neurol 2012; 8: 700-10. http://dx.doi.org/10.1038/nrneurol.2012.223
22. Glueck CJ, Aregawi D, Goldenberg N, et al. Idiopathic intracranial hypertension, polycysticovary syndrome, and thrombophilia. J Lab Clin Med 2005; 145 (2): 72-82.

http://dx.doi.org/10.1016/j.lab.2004.09.011

23. Antonopoulou M, Sharma R, Farag A, et al. Hypopituitarism in the elderly. Maturitas 2012; 72 (4): 277-85.

http://dx.doi.org/10.1016/j.maturitas.2012.05.002

24. Biousse V, Bruce BB, Newman NJ. Update on the pathophysiology and management of idiopathic intracranial hypertension. J Neurol Neurosur Ps 2012; 83: 488-94.

http://dx.doi.org/10.1136/jnnp-2011-302029

25. Donaldson J, Horak E. Cerebrospinal fluid oestrone in pseudotumourcerebri. J Neurol Neurosur Ps 1982; 45: 734-66.

http://dx.doi.org/10.1136/jnnp.45.8.734

26. Pollak L, Zohar E, Glovinsky Y, Huna-Baron R. Reevaluation of presentation and course of idiopathic intracranial hypertension - a large cohort comprehensive study. Acta Neurol Scand 2013; DOI: 10.1111/ane.12060 http://dx.doi.org/10.1111/ane.12060

27. Bruce BB, Kedar S, Van Stavern GP, et al. Atypical idiopathic intracranial hypertension. Normal BMI and older patients. Neurology 2010; 74 (22): 182732.

http://dx.doi.org/10.1212/WNL.0b013e3181e0f838

28. Friedman DI. Idiopathic intracranial hypertension. Curr Pain Headache R 2007; 11 (1): 62-8. http://dx.doi.org/10.1007/s11916-007-0024-8

29. Ooi LY, Walker BR, Bodkin PA, Whittle IR. Idiopathic intracranial hypertension: Can studies of obesity provide the key to understanding pathogenesis? British J Neurosurg 2008; 22 (2): 18794.

http://dx.doi.org/10.1080/02688690701827340

30. Digre K, Corbett J. Pseudotumourcerebri in men. Arch Neurol 1998; 45: 866-72. http://dx.doi.org/10.1001/archneur.1988.00520320056015 
31. Nedelmann M, Kaps M, Mueller-Forell W. Venous obstruction and jugular valve insufficiency in idiopathic intracranial hypertension. J Neurol 2009; 256 (6): 964-9.

http://dx.doi.org/10.1007/s00415-009-5056-z

32. Batra S, Miller NR, Subramanian PS, et al. PseudotumorCerebri Syndrome: A Review. Contemporary Neurosurgery 2013; 35 (2): 1-8. http://dx.doi.org/10.1097/01.CNE.0.27121.4c

33. Anat K, Efrat K, Einor Ben A, et al. Thrombophilic factors in idiopathic intracranial hypertension: a report of 51 patients and a meta-analysis. Blood Coagul Fibrin 2010; 21 (4): 328-33.

http://dx.doi.org/10.1097/MBC.0b013e8ce12

34. Farb RI, Vanek I, Scott JN, et al. Idiopathic intracranial hypertension: the prevalence and morphology of sinovenous stenosis. Neurology 2003; 60 (9): 1418-24.

http://dx.doi.org/10.1212/01.WNL.0000066683.34093.E2

35. Silberstein SD, McKinstry RC. The death of idiopathic intracranial hypertension? Neurology 2003; 60 (9): 1406-7.

http://dx.doi.org/10.1212/01.WNL.0000070103.72017.1D

36. Safavi-Abbasi S, Di Rocco F, Nakaji P, et al. Thrombophilia due to factor $\mathrm{V}$ and factor II mutations and formation of a duralarteriovenous fistula: case report and review of a rare entity. Skull Base 2008; 18 (2): 135-42.

http://dx.doi.org/10.1055/s-2007-1003926

37. Higgins JNP, Gillard JH, Owler BK, et al. MR venography in idiopathic intracranial hypertension: unappreciated and misunderstood. J Neurol Neurosur Ps 2004; 75 (4): 621-5. http://dx.doi.org/10.1136/jnnp.2003.021006
38. Ayanzena RH, Bird CR, Kellera PJ, et al. Cerebral MR venography: normal anatomy and potential diagnostic pitfalls. Am J Neuroradiol 2000; 21: 74-8.

39. Kapoor KG. Etiology of dizziness, tinnitus, and nausea in idiopathic intracranial hypertension. Med Hypotheses 2008; 71 (2): 310-11.

http://dx.doi.org/10.1016/j.mehy.2008.03.018

40. Wall M. Idiopathic Intracranial Hypertension and the Idiopathic Intracranial Hypertension Treatment Trial. J Neuro-Ophthalmol 2013; 33 (1): 1-3. http://dx.doi.org/10.1097/WNO.0b013e3182819aee

41. Shah VA, Kardon RH, Lee AG, et al. Long-term follow-up of idiopathic intracranial hypertension: the Iowa experience. Neurology 2008; 70: 634-40. http://dx.doi.org/10.1212/01.wnl.0000299893.43918.a8

42. Baheti NN, Nair M, Thomas SV. Long-term visual outcome in idiopathic intracranial hypertension. Ann Indian Acad Neurol 2011; 14(1): 19-22. http://dx.doi.org/10.4103/0972-2327.78044

43. Alperin N, Ranganathan S, Bagci AM, et al. MRI Evidence of Impaired CSF Homeostasis in ObesityAssociated Idiopathic Intracranial Hypertension. Am J Neuroradiol 2012; doi: 10.3174/ajnr.A3171 http://dx.doi.org/10.3174/ajnr.A3171

44. Friedman DI. Medication-Induced Intracranial Hypertension in Dermatology. Am J ClinDermatol 2005; 6 (1): 29-37.

http://dx.doi.org/10.2165/00128071-200506010-00004

45. Thurtell MJ, Wall M. Idiopathic Intracranial Hypertension (PseudotumorCerebri): Recognition, Treatment, and Ongoing Management. Curr Treat Option Ne 2013; 15 (1): 1-12. http://dx.doi.org/10.1007/s11940-012-0207 


\title{
Idiopatska intrakranijalna hipertenzija - patofiziologija bazirana na seriji slučajeva
}

\author{
Srđan Ljubisavljević1,2, Jasna Zidverc Trajković3,4 \\ ${ }^{1}$ Univerzitet $u$ Nišu, Medicinski fakultet, Niš, Srbija \\ ${ }^{2}$ Klinika za neurologiju, Klinički centar Niš, Srbija \\ ${ }^{3}$ Univerzitet u Beogradu, Medicinski fakultet, Beograd, Srbija \\ ${ }^{4}$ Klinika za neurologiju, Klinički centar Srbije, Beograd, Srbija
}

\section{SAŽETAK}

Idiopatska intrakranijalna hipertenzija (IIH) je definisana kao patološko stanje koje karakteriše porast intrakranijalnog pritiska u odsustvu intrakranijalnog patološkog procesa koji bi mogao biti objašnjenje za taj porast. Patofiziologija ovog poremećaja još uvek nije sasvim razjašnjena, uprkos brojnim istraživanjima koja su tome posvećena.

U ovom radu autori prikazuju pregled mogućih etiopatogenetskih mehanizama, kliničke prezentacije i terapijskih mogućnosti iz serije bolesnika hospitalizovanih sa kliničkom slikom i konačnom dijagnozom IIH. Analizirani su podaci u momentu postavljanja dijagnoze IIH i tri meseca kasnije.

Dobijeni rezultati ukazuju da je IIH bolest sa većom prevalencijom kod gojaznih žena u mlađem i srednjem životnom dobu. Uočena je pozitivna korelacija između vrednosti pritiska cerebrospinalne tečnosti $\mathbf{i}$ indeksa telesne mase. Disbalans polnih hormona izdvojen je kao moguća etiologija IIH kod žena. Glavobolja, edem papile optičkog nerva, pad vidne oštrine, vrtoglavica i oštećenje kranijalnih nerava prepoznati su kao najčešća klinička prezentacija IIH. Postojanje stenoze i hipoplazije sigmoidnog $i$ transverzalnog sinusa potvrđeno je kod trećine ispitivanih bolesnika. Farmakoterapija, u kombinaciji sa redukcijom telesne mase, bila je efikasna terapijska opcija kod velikog broja bolesnika. U prikazanoj seriji nije bilo neposrednih kliničkih komplikacija IIH.

Prikazani rezultati ukazuju na značaj ranog i pažljivog traganja za IIH kod gojaznih žena u mlađem i srednjem životnom dobu kod kojih postoji disbalans polnih hormona i koje imaju različitu neurološku simptomatologiju, najčešće manifestovanu u vidu glavobolje i smetnji vida. Rana dijagnoza IIH omogućava pravovremenu terapiju čijom bi se primenom mogle prevenirati i neposredne i odložene kliničke komplikacije IIH.

Ključne reči: idiopatska intrakranijalna hipertenzija, glavobolje, patofiziologija 